\title{
Optimum Extraction of Groundwater for Sustainable Use in Watershed Areas
}

\author{
Vaishnavi $^{*}$, G. B. Lokesh ${ }^{1}$, T. J. Amrutha ${ }^{1}$, Jagrati B. Deshmanya ${ }^{1}$ \\ and G. V. Srinivasa Reddy ${ }^{2}$ \\ ${ }^{1}$ Department of Agricultural Economics, ${ }^{2}$ Department of Soil and Water Engineering, \\ University of Agricultural Sciences, Raichur, 584104, India \\ *Corresponding author
}

\begin{tabular}{|l|}
\hline Key w or d s \\
Groundwater, \\
Watershed, \\
Optimum \\
extraction, \\
Sustainable \\
management
\end{tabular}

Land and water resources are the basic

\section{Introduction}

The present study was undertaken to analyze the optimum extraction of groundwater in watershed areas for sustainable use. There was lack of efficient irrigation facility is the major cause for low agricultural productivity in Karnataka due to its over exploitation is leading to continuous decline in the groundwater table. The study was followed purposive random sampling for selection of micro-watersheds and based on the primary data all groundwater irrigated farmers of respective micro-watershed areas were interviewed. A sensitive analysis was carried out to know the groundwater used for optimal as well as sustainable patterns of groundwater management. The results showed that in study area, cropping intensity of Kavalakeri-4 and Ryavanki-1 micro-watershed area was about 160.25 and 157.52 per cent respectively. And Chattar-1 and Kumarkhed micro-watershed area was about 148.45 and 118.48 per cent respectively. The optimal groundwater usage for major crops showed that there was higher groundwater usage than required in crops like chilli, sugarcane, maize in micro-watershed areas of Koppal and redgram, onion, bajra in micro-watershed areas of Raichur district. By optimizing the existing water usage for major crops can reduce the overuse of groundwater indicating the sustainable management of groundwater in micro-watershed areas. Strategies for groundwater usage and optimum extraction must be based on adoption of cropping pattern, modern irrigation approach, rainfall and other agro climatic conditions for sustainable use of groundwater to improve livelihood of the farmers. Hence the government policy needs to be oriented towards these to motivate farmers to adopt micro (drip \& sprinkler) irrigation. In addition, it is essential to promote irrigation literacy to enable farmers to use water efficiently. resources for agriculture and it plays an important role in shaping the economic development of the country. The demands for 
these resources are continuously increasing with the rising population. Agriculture is the predominant sector that enhances rural livelihood for nearly 60 per cent of the rural population. There are seven river systems in the State viz., Krishna, Cauvery, Godavari, West Flowing Rivers, North Pennar, South Pennar and Palar. Utilization of water in the West Flowing Rivers is hampered due to difficulties in construction of large storage reservoirs. Yield in the seven river basins is estimated as 3,418 TMC at 50 per cent dependability and 2,934 TMC at 75 per cent dependability. The economically utilizable water for irrigation is estimated at 1,695 TMC (Chandrakanth, 2009).

Groundwater is another important source for meeting nearly half of the demand for irrigation, industrial production and municipal water needs of both rural and urban areas in Karnataka. The total replenishable groundwater potential for the state is estimated at 17.03 Billion Cubic Meters (BCM) received from both monsoon and non-monsoon seasons (rainfall constitutes $9.48 \mathrm{BCM}$ and recharge of $7.55 \mathrm{BCM}$ from other sources). It is estimated that $2.2 \mathrm{BCM}$ of water is naturally discharged during the non-monsoon period and net availability of groundwater is 14.81 BCM. The total annual groundwater draft (9.41 BCM) for irrigation and domestic and industrial use is estimated at 8.59 and 0.28 $\mathrm{BCM}$ respectively. Karnataka has already over drafted groundwater by 64 per cent and 6.53 BCM is available for future use (Anon., 2014). Groundwater usage and its development is also controlled by the socio-economic conditions of the farmers apart from the technical feasibility. The factors which determine the extinct of groundwater use are the cropping pattern, crop water requirement, groundwater management, policy interventions in groundwater extraction and well density. Excessive usage of groundwater will lead to its irreversible degradation.
Water policies focus relatively on the demand side of water (Million wells scheme, subsidy for micro irrigation, conveyance pipes, energy subsidy) neglecting the supply side of water (or lack of efforts towards recharging well) affecting its sustainable use. Use of groundwater in optimum levels is most important among all resources. This study will help to know the changing groundwater use pattern in agriculture and its impact on livelihood of farmers. In $\mathrm{H}-\mathrm{K}$ region, in this context, the present study is carried out with the following specific objective, to estimate the optimum extraction of groundwater in watershed area for sustainable use.

\section{Materials and Methods}

The study was conducted in Kavalkeri-4, Ryavanaki-1 micro-watersheds of Koppal and Chattar-1, Kumarkhed micro-watersheds of Raichur district, Karnataka with purposive random sampling method. The data were collected from the respondent farmers during 2018-19. The farmers were interviewed personally using a structured pre tested schedule in each micro-watershed area. The data pertaining to cropping pattern and optimization of the existing water used for major crops in each micro-watershed.

\section{Linear programming}

To obtain the optimal groundwater usage for each crop in each micro-watershed area, the linear programming method was used. The objective function was to minimize groundwater extraction for each crop grown in each micro watershed area. The mathematical model was of the following form:

Minimize $\mathrm{Z}=\sum_{\mathrm{i}=1}^{\mathrm{n}} \mathrm{WiXi}------------1$

Where, 
$\mathrm{Z}=$ Aggregate groundwater extraction from the crops in given micro watershed

$\mathrm{W}_{\mathrm{i}}=$ Volume of Groundwater extracted from each $i^{\text {th }}$ crop (acre inch)

$\mathrm{X}_{\mathrm{i}}=$ Crop grown under each micro watershed area

Subject to constraints

$\sum_{\mathrm{i}=1}^{\mathrm{n}} \mathrm{AiXi}-----------2$

Where,

$A_{i}=$ area of each crop grown

$\sum_{i=1}^{n} N R i X i----------3$

Where,

$\mathrm{NR}_{\mathrm{i}}=$ Net returns of each crop grown

$\sum_{\mathrm{i}=1}^{\mathrm{n}}$ WeiXi----- -------4

Where,

$\mathrm{We}_{\mathrm{i}}=$ Water use efficiency of each crop grown

\section{Results and Discussion}

To meet the objective of the study, cropping pattern followed in Kavalakeri-4 microwatershed it was seen from the Table 1 that during kharif season major area was occupied by maize $(39.20 \%)$ of total gross cropped area followed by sugarcane $(8.00 \%)$, bajra $(5.60 \%)$, vegetables $(4.00 \%)$ and redgram $(3.20 \%)$. Whereas in rabi season major area was occupied by groundnut (20.80\%) followed by chilli (6.40\%), wheat $(5.60 \%)$, chickpea (4.80\%) and cowpea $(2.40 \%)$.

In another micro-watershed area Ryavanki-1 during kharif season major area occupied by maize that was 26.40 per cent of total gross cropped area followed by sunflower (16.29\%), sugarcane $(11.24 \%)$, vegetables $(8.43 \%)$, bajra (3.37\%), cotton and redgram (1.69\%) and during rabi season major area occupied by groundnut $(9.55 \%)$ of total gross cropped area followed by chickpea $(6.18 \%)$, chilli $(5.62 \%)$ and wheat, sorghum, onion $(2.81 \%)$ of total gross cropped area and the cropping intensity of Kayalakeri-4 and Ryavanki-1 microwatershed area was about 160.25 and 157.52 per cent respectively (Table1).

In similar way, cropping pattern followed in Chattar-1 micro-watershed of Raichur district was presented in Table 2. It was observed that during kharif season major area occupied by bajra (31.94\%) followed by redgram $(28.47 \%)$, sesamum (12.50\%) and vegetables $(4.86 \%)$ of total gross cropped area.

Whereas in rabi season major area occupied by chilli (6.94\%), groundnut and onion $(3.47 \%)$, sorghum and cowpea $(2.08 \%)$, wheat and chickpea $(1.39 \%)$ of total gross cropped area.

Whereas in Kumarkhed micro-watershed area during kharif season major gross cropped area occupied by bajra was 37.59 per cent followed by redgram $(21.99 \%)$, sesamum $(14.89 \%)$ and vegetables $(3.55 \%)$ and during rabi season major area occupied by onion (5.67\%), chilli $(4.26 \%)$, sorghum and cowpea (2.84\%), chickpea $(2.13 \%)$ and groundnut $(1.42 \%)$ of total gross cropped area and the cropping intensity of Chattar-1 and Kumarkhed microwatershed area were about 148.45 and 118.48 percent respectively (Table 2). Cropping intensity is one of the measuring indices for land use efficiency. The cropping intensity 
depends on many factors viz., natural conditions (like rainfall and climate) and also socio economic factors. However, given the situation the cropping intensity of respondent farmers was more than 100 per cent indicating efficient utilization of land. Wherein Table 1 and Table 2 showed that most of the crops were irrigated through groundwater because of the availability of water throughout the year.

\section{Optimal groundwater usage for major crops}

The analysis of optimal groundwater usage among major crops in Kavalakeri-4 microwatershed carried out. The existing groundwater usage for maize (11.72 ac/inches) followed by groundnut ( 9.25 ac/inches), chilli (11.15 ac/inches), sugarcane (35.94 ac/inches).

In optimal plan, groundwater usage for maize (9.97 ac/inches) followed by groundnut (8.93 ac/inches), chilli (10.54 ac/inches), sugarcane (35.41 ac/inches). Hence, results showed that there was reduction of groundwater usage was found more in maize (14.93\%) followed by chilli $(5.51 \%)$, groundnut $(3.46 \%)$.

Whereas in Ryavanaki-1 micro-watershed existing groundwater usage for maize (11.77 ac/inches) followed by groundnut (9.43 ac/inches), chilli (12.01 ac/inches), sugarcane (34.59 ac/inches). In optimal plan, groundwater usage for maize (10.56 ac/inches) followed by groundnut ( $9.11 \mathrm{ac} /$ inches $)$, chilli (11.05 ac/inches), sugarcane (34.13 ac/inches). Hence, results showed that there was higher reduction of groundwater usage was found for maize $(10.28 \%)$ followed by chilli $(7.99 \%)$, groundnut $(3.39 \%)$ (Table 3$)$.

In similar way optimal groundwater usage among major crops in Chattar-1 microwatershed carried out. The existing groundwater usage for bajra (6.48 ac/inches) followed by redgram (7.83 ac/inches), sesamum (11.54 ac/inches), onion (10.85 ac/inches). In optimal plan, groundwater usage for bajra (5.88 ac/inches) followed by redgram (6.05 ac/inches), sesamum (11.31 ac/inches), onion (9.68 ac/inches). Hence, results showed that there was higher reduction of groundwater usage was found for bajra $(9.25 \%)$ followed by redgram $(22.74 \%)$, sesamum $(1.99 \%)$, onion (10.78\%). Whereas in Kumarkhed micro-watershed existing groundwater usage for bajra (6.61 ac/inches) followed by redgram (7.74 ac/inches), sesamum (11.72 ac/inches), onion (10.13 ac/inches). In optimal plan, groundwater usage for bajra (6.09 ac/inches) followed by redgram (5.13 ac/inches), sesamum (10.78 ac/inches), onion (9.06 ac/inches). Hence, similar results were showed that there was reduction of groundwater usage found was more in bajra $(7.87 \%)$ followed by redgram $(33.70 \%)$, sesamum $(8.02 \%)$ and onion $(10.60 \%$ ) (Table 4$)$. The similar study about optimal crop plan was carried out in Perambalur district of Tamil Nadu by Mahendran et al., (2006).

The results of this study shown that the cropping pattern in micro-watershed areas under given situation the cropping intensity of respondent farmers was more than 100 percent indicating efficient utilization of land.

And also the results of the optimal groundwater usage for major crops showed that there was higher groundwater usage in crops like redgram, onion, bajra in microwatershed areas.

It might be due to reasons like flood irrigation method, increase in number of hours of pumping etc. Over utilization of groundwater for irrigation than the optimum level due to lack of adequate knowledge and also more inefficiency was found among the traditional groundwater users, which causes overexploitation of groundwater. 
Table.1 Cropping pattern of respondent farmers in Koppal district, 2018-19

\begin{tabular}{|c|c|c|c|c|c|c|c|c|c|}
\hline \multirow[t]{2}{*}{ Season } & \multirow[t]{2}{*}{ Crop } & \multicolumn{4}{|c|}{$\begin{array}{c}\text { Kavalakeri-4 (MW) } \\
(n=16)\end{array}$} & \multicolumn{4}{|c|}{$\begin{array}{c}\text { Ryavanaki-1 (MW) } \\
(\mathbf{n}=15)\end{array}$} \\
\hline & & $\begin{array}{l}\text { Groundwater } \\
\text { Irrigated } \\
\text { (acre) }\end{array}$ & $\begin{array}{l}\text { Rainfed } \\
\text { (acre) }\end{array}$ & Total & $\begin{array}{l}\text { \% to gross } \\
\text { cropped } \\
\text { area }\end{array}$ & $\begin{array}{c}\text { Groundwater } \\
\text { Irrigated } \\
\text { (acre) }\end{array}$ & $\begin{array}{l}\text { Rainfed } \\
\text { (acre) }\end{array}$ & Total & $\begin{array}{c}\% \text { to gross } \\
\text { cropped } \\
\text { area }\end{array}$ \\
\hline \multirow[t]{7}{*}{ Kharif } & Redgram & - & 4 & 4 & 3.20 & - & 3 & 3 & 1.69 \\
\hline & Maize & 45 & 4 & 49 & 39.20 & 32 & 15 & 47 & 26.40 \\
\hline & Cotton & - & - & - & - & - & 3 & 3 & 1.69 \\
\hline & Bajra & - & 7 & 7 & 5.60 & - & 6 & 6 & 3.37 \\
\hline & Sunflower & - & - & - & - & 19 & 10 & 29 & 16.29 \\
\hline & Vegetables & 5 & - & 5 & 4.00 & 15 & - & 15 & 8.43 \\
\hline & Sugarcane & 10 & - & 10 & 8.00 & 20 & - & 20 & 11.24 \\
\hline \multirow{7}{*}{ Rabi } & Wheat & 4 & 3 & 7 & 5.60 & 5 & - & 5 & 2.81 \\
\hline & Sorghum & - & - & - & - & - & 5 & 5 & 2.81 \\
\hline & Cowpea & 3 & - & 3 & 2.40 & - & - & - & - \\
\hline & Chickpea & 4 & 2 & 6 & 4.80 & 6 & 5 & 11 & 6.18 \\
\hline & Groundnut & 26 & - & 26 & 20.80 & 15 & 2 & 17 & 9.55 \\
\hline & Onion & - & - & - & - & 5 & - & 5 & 2.81 \\
\hline & $\begin{array}{l}\text { Chilli (seed } \\
\text { production) }\end{array}$ & 8 & - & 8 & 6.40 & 10 & - & 10 & 5.62 \\
\hline \multirow{4}{*}{$\begin{array}{l}\text { Annual/ } \\
\text { perennial } \\
\text { crop }\end{array}$} & Mango & - & - & - & - & 2 & - & 2 & 1.12 \\
\hline & $\begin{array}{c}\text { Gross } \\
\text { cropped area } \\
\text { (acres) }\end{array}$ & 105 & 20 & 125 & 100.00 & 129 & 49 & 178 & 100.00 \\
\hline & $\begin{array}{l}\text { Net Cropped } \\
\text { area (acres) }\end{array}$ & 63 & 15 & 78 & 100.00 & 76 & 37 & 113 & 100.00 \\
\hline & $\begin{array}{c}\text { Cropping } \\
\text { Intensity } \\
(\%)\end{array}$ & \multicolumn{4}{|c|}{160.25} & \multicolumn{4}{|c|}{157.52} \\
\hline
\end{tabular}


Table.2 Cropping pattern of respondent farmers in Raichur district, 2018-19

\begin{tabular}{|c|c|c|c|c|c|c|c|c|c|}
\hline \multirow[t]{2}{*}{ Season } & \multirow[t]{2}{*}{ Crop } & \multicolumn{4}{|c|}{$\begin{array}{c}\text { Chattar-1 (MW) } \\
(n=18)\end{array}$} & \multicolumn{4}{|c|}{$\begin{array}{c}\text { Kumarkhed (MW) } \\
(\mathrm{n}=16)\end{array}$} \\
\hline & & $\begin{array}{l}\text { Groundwater } \\
\text { Irrigated } \\
\text { (acre) }\end{array}$ & $\begin{array}{c}\text { Rainfed } \\
\text { (acre) }\end{array}$ & Total & $\begin{array}{c}\% \text { to } \\
\text { gross } \\
\text { cropped } \\
\text { area }\end{array}$ & $\begin{array}{l}\text { Groundwater } \\
\text { Irrigated } \\
\text { (acre) }\end{array}$ & $\begin{array}{c}\text { Rainfed } \\
\text { (acre) }\end{array}$ & Total & $\begin{array}{c}\% \text { to } \\
\text { gross } \\
\text { cropped } \\
\text { area }\end{array}$ \\
\hline \multirow[t]{4}{*}{ Kharif } & Redgram & 38 & 3 & 41 & 28.47 & 23 & 8 & 31 & 21.99 \\
\hline & Bajra & 33 & 13 & 46 & 31.94 & 31 & 22 & 53 & 37.59 \\
\hline & Sesamum & 15 & 3 & 18 & 12.50 & 17 & 4 & 21 & 14.89 \\
\hline & Vegetables & 7 & - & 7 & 4.86 & 5 & - & 5 & 3.55 \\
\hline \multirow{7}{*}{ Rabi } & Wheat & - & 2 & 2 & 1.39 & - & - & 0 & 0.00 \\
\hline & Sorghum & - & 3 & 3 & 2.08 & - & 4 & 4 & 2.84 \\
\hline & Cowpea & 3 & - & 3 & 2.08 & 4 & - & 4 & 2.84 \\
\hline & Chickpea & 2 & & 2 & 1.39 & 3 & - & 3 & 2.13 \\
\hline & Groundnut & 5 & - & 5 & 3.47 & 2 & - & 2 & 1.42 \\
\hline & Onion & 5 & - & 5 & 3.47 & 8 & - & 8 & 5.67 \\
\hline & $\begin{array}{l}\text { Chilli (seed } \\
\text { production) }\end{array}$ & 10 & - & 10 & 6.94 & 6 & - & 6 & 4.26 \\
\hline \multirow{4}{*}{$\begin{array}{l}\text { Annual/ } \\
\text { perennial } \\
\text { crop }\end{array}$} & Guava & 2 & - & 2 & 1.39 & 4 & - & 4 & 2.84 \\
\hline & $\begin{array}{c}\text { Gross } \\
\text { cropped area } \\
\text { (acres) }\end{array}$ & 120 & 24 & 141 & 100.00 & 103 & 38 & 141 & 100.00 \\
\hline & $\begin{array}{l}\text { Net Cropped } \\
\text { area (acres) }\end{array}$ & 78 & 19 & 97 & 100.00 & 85 & 34 & 119 & 100.00 \\
\hline & $\begin{array}{c}\text { Cropping } \\
\text { Intensity } \\
(\%)\end{array}$ & \multicolumn{4}{|c|}{148.45} & \multicolumn{4}{|c|}{118.48} \\
\hline
\end{tabular}


Table.3 Optimal groundwater usage for major crops using linear programming in Koppal district

\begin{tabular}{|c|c|c|c|c|c|c|c|}
\hline Sl. & Crop & \multicolumn{2}{|c|}{ Kavalakeri-4 (MW) } & \multicolumn{3}{c|}{ Ryavanaki-1 (MW) } \\
\cline { 3 - 8 } & $\begin{array}{c}\text { Existing } \\
\text { groundwater } \\
\text { usage(acre } \\
\text { inches) }\end{array}$ & $\begin{array}{c}\text { Optimal } \\
\text { groundwater } \\
\text { usage }(\text { acre } \\
\text { inches) }\end{array}$ & $\begin{array}{c}\text { Water } \\
\text { saving } \\
(\%)\end{array}$ & $\begin{array}{c}\text { Existing } \\
\text { groundwater } \\
\text { usage (acre } \\
\text { inches) }\end{array}$ & $\begin{array}{c}\text { Optimal } \\
\text { groundwater } \\
\text { usage (acre } \\
\text { inches) }\end{array}$ & $\begin{array}{c}\text { Water } \\
\text { saving } \\
(\%)\end{array}$ \\
\hline $\mathbf{1}$ & Maize & 11.72 & 9.97 & 14.93 & 11.77 & 10.56 & 10.28 \\
\hline $\mathbf{2}$ & Groundnut & 9.25 & 8.93 & 3.46 & 9.43 & 9.11 & 3.39 \\
\hline $\mathbf{3}$ & $\begin{array}{c}\text { Chilli (seed } \\
\text { production) }\end{array}$ & 11.15 & 10.54 & 5.51 & 12.01 & 11.05 & 7.99 \\
\hline $\mathbf{4}$ & Sugarcane & 35.94 & 35.41 & 1.49 & 34.59 & 34.13 & 1.33 \\
\hline & Total & $\mathbf{6 8 . 0 6}$ & $\mathbf{6 4 . 8 4}$ & $\mathbf{4 . 7 3}$ & $\mathbf{6 7 . 8 0}$ & $\mathbf{6 4 . 8 5}$ & $\mathbf{4 . 4 8}$ \\
\hline
\end{tabular}

Table.4 Optimal groundwater usage for major crops using linear programming in Raichur district

\begin{tabular}{|c|c|c|c|c|c|c|c|}
\hline Sl. & Crop & \multicolumn{3}{|c|}{ Chattar-1 (MW) } & \multicolumn{3}{c|}{ Kumarkhed (MW) } \\
\cline { 3 - 8 } No. & $\begin{array}{c}\text { Existing } \\
\text { groundwater } \\
\text { usage(acre } \\
\text { inches) }\end{array}$ & $\begin{array}{c}\text { Optimal } \\
\text { groundwater } \\
\text { usage }(\text { acre } \\
\text { inches) }\end{array}$ & $\begin{array}{c}\text { Water } \\
\text { saving }(\%)\end{array}$ & $\begin{array}{c}\text { Existing } \\
\text { groundwater } \\
\text { usage (acre } \\
\text { inches) }\end{array}$ & $\begin{array}{c}\text { Optimal } \\
\text { groundwater } \\
\text { usage (acre } \\
\text { inches) }\end{array}$ & $\begin{array}{c}\text { Water } \\
\text { saving } \\
(\%)\end{array}$ \\
\hline $\mathbf{1}$ & Bajra & 6.48 & 5.88 & 9.25 & 6.61 & 6.09 & 7.87 \\
\hline $\mathbf{2}$ & Redgram & 7.83 & 6.05 & 22.74 & 7.74 & 5.13 & 33.70 \\
\hline $\mathbf{3}$ & Sesamum & 11.54 & 11.31 & 1.99 & 11.72 & 10.78 & 8.02 \\
\hline $\mathbf{4}$ & Onion & 10.85 & 9.68 & 10.78 & 10.13 & 9.06 & 10.60 \\
\hline & Total & $\mathbf{3 6 . 7 0}$ & $\mathbf{3 2 . 9 2}$ & $\mathbf{1 0 . 3 0}$ & $\mathbf{3 6 . 2 0}$ & $\mathbf{3 1 . 0 6}$ & $\mathbf{1 4 . 2 0}$ \\
\hline
\end{tabular}

And for this government need to be educated and motivated to farmers to invest on low water consumption technologies like drip irrigation and sprinkler irrigation for conservation of groundwater.

The deficiency of water resources in microwatershed areas can be overcome by harvesting the available potential of runoff and efficient utilization by increasing micro irrigation techniques to the entire area and also decreasing area of high water required crops and modifying in cropping pattern to reduce the groundwater decline which contributing to sustainable groundwater management. There is a need for planning of optimum groundwater use in each micro-watershed of the state based on rainfall, cropping pattern and other agro climatic conditions for sustainable use of groundwater to improve livelihood of the farmers. Hence efforts should be made to include groundwater management as a one of the importance component in watershed programmes.

\section{References}

Anonymous, 2014, Ministry of Water Resources, River Development and Ganga Rejuvenation. GOI.

Chandrakanth, M. G., 2009, Karnataka state water sector reform: Current status, 
emerging issues and needed strategies. International Water Management Institute (IWMI).

Mahendran, R., Chandrashekaran, M. and Gurunathan, S., 2006, A Study on evolving optimal cropping patterns in ground water over-exploited region of perambalur district of Tamil Nadu. Agricultural Economics Research
Review, 19: 95-108.

Srivastava, S. K., Kumar Ranjit. and Singh R. P., 2009, Extent of Groundwater extraction and irrigation efficiency on farms under different water-market regimes in Central Uttar Pradesh. Agricultural Economics Research Review, 22: 87-97.

\section{How to cite this article:}

Vaishnavi, G. B. Lokesh, T. J. Amrutha, Jagrati B. Deshmanya and Srinivasa Reddy, G. V. 2019. Optimum Extraction of Groundwater for Sustainable Use in Watershed Areas. Int.J.Curr.Microbiol.App.Sci. 8(10): 1549-1556. doi: https://doi.org/10.20546/ijcmas.2019.810.180 